Gi respons på artikler gjennom artiklenes kommentarfelt på tidsskriftet.no.

Innleggene publiseres fortløpende på Tidsskriftets nettside og et utvalg

av innleggene publiseres også i papirutgaven i spalten «Brev til redaktøren».

Redaksjonen forbeholder seg retten til å foreta redaksjonelle endringer.

Forfattere av vitenskapelige artikler har tilsvarsrett, jf. Vancouver-gruppens regler

Myndighetenes beslutning om massevaksinasjon under svineinfluensaen har blitt debattert på Tidsskriftets nettsider i etterkant av professor Elling Ulvestad kritiske uttalelser i portrettintervjuet «Jakten på det utenomjordiske» i Tidsskriftet nr. 12/2014. Her følger tre nye innlegg. Debatten kan leses $i$ sin helhet på Tidsskriftets nettsider.

\section{Re: Jakten på det utenomjordiske}

Svineinfluensaviruset slo til i Mexico City tidlig på året 2009, og alarmen ble «slått av» der før sykdommen rammet Norge. Gjennom ukentlige statistikker fra Mexico var det lett å regne seg fram til hvordan viruset ville oppføre seg. Derfor mener jeg «skandale» er en riktig beskrivelse av håndteringen $\mathrm{i}$ Norge.

\section{Eldar Solum \\ E4s7@online.no}

Eldar Solum (f. 1947) er allmennlege i Sande i Vestfold.

Ingen oppgitte interessekonflikter.

\section{Re: Jakten på det utenomjordiske}

Pandemihåndteringen i Danmark ble i 2013 drøftet i regjeringen og Stortinget (1): Allerede 26. juni 2009 bestilte danske myndigheter Pandemrix til bare helsepersonell og risikogruppene. Norske helsemyndigheter delte danskenes nøkterne risikovurdering (2), men ventet med anbefalinger til sikrere kunnskap om epidemien og vaksinen var tilgjengelig. I begge land ble kostnader og nytte av vaksinasjon vurdert uten å bli satt inn i en større samfunnsøkonomisk modell. Norske helsemyndigheter vektet nok farene for alvorlig sykdom og død mer enn de danske.

Den tidlige, danske beslutningen fikk flere uheldige konsekvenser:

En «heftig debat» brøt løs da epidemien kom til Danmark utpå høsten, og myndighetene ikke hadde vaksiner til befolkningen (1).

De første ukene var få doser tilgjengelig slik at bare $20 \%$ av risikogruppene ble vaksinert (2). Norge fikk tre ganger så mange doser per uke som Danmark, siden vår totalbestilling var tre ganger så stor.

Den lave vaksinasjonsdekningen ( $6 \%$ mot over $40 \%$ i Norge) gjorde at Danmark høsten 2010 hadde lav befolkningsimmunitet. Dette førte til en stor epidemi også den andre pandemisesongen (2010-2011) med 106 innleggelser på intensivavdeling (mot 93 i 2009-2010) og 53 dødsfall (mot 30 i 2009-2010) tilskrevet svineinfluensa. I Norge, Sverige og Finland var tallene mye lavere i 2010-2011 sammenliknet med 2009-2010 og sammenliknet med Danmark i 2010-2011.

Sundhedsstyrelsen måtte leve med en usikkerhet om at epidemien skulle bli verre (3): «Vi kan ikke bare ændre på den strategi, vi har valgt (...). For vaccinen er en mangelvare, og vi kan ikke bare købe løs af den.»

Data om Pandemrix, ikke andre vaksiner, var basis for legemiddelmyndighetenes godkjenning og helsemyndighetenes informasjon, inkludert forventningen om minst $70 \%$ beskyttelse. Forventningen ble oppfylt (4-5).

Ulvestad påsto feilaktig at jeg mener at «massevaksinasjonen var «den største vaksineskandalen i moderne tid»». Han bør beklage uttalelsen og sitatfusket.

Ulvestad evner fortsatt ikke å bevise at helsemyndighetene drev med «illegitim bruk av frykt for å få folk til å vaksinere seg» mot svineinfluensa, til tross for at han har hatt god anledning til å saumfare dokumentasjonen fra pandemien. Påstanden kan dermed nå avskrives som falsk.

\section{Preben Aavitsland}

preben@epidemi.no

Preben Aavitsland (f. 1963) er lege ved Epidemi.

Interessekonflikter: Aavitsland har hatt sentrale roller i Folkehelseinstituttets håndtering av svineinfluensapandemien og i instituttets egenevaluering av håndteringen.

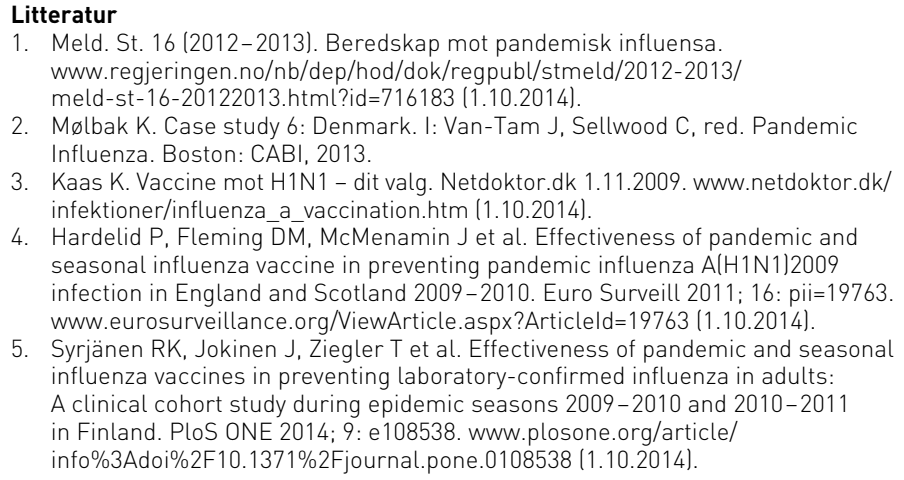

3. Kaas K. Vaccine mot H1N1 - dit valg. Netdoktor.dk 1.11.2009. www.netdoktor.dk/ infektioner/influenza_a_vaccination.htm (1.10.2014)

4. Hardelid P. Fleming $\bar{D} \bar{M}$, McMenamin J et al. Effectiveness of pandemic and seasonal influenza vaccine in preventing pandemic influenza A(H1N1)2009 infection in England and Scotland 2009-2010. Euro Surveill 2011; 16: pii=19763. www.eurosurveillance.org/ViewArticle.aspx?Articleld=19763 (1.10.2014)

5. Syrjänen RK, Jokinen J, Ziegler T et al. Effectiveness of pandemic and seasonal influenza vaccines in preventing laboratory-confirmed influenza in adults: A clinical cohort study during epidemic seasons 2009-2010 and 2010-2011 in Finland. PloS ONE 2014: 9: e108538. www.plosone.org/article/ info\%3Adoi\%2F10.1371\%2Fjournal.pone.0108538 (1.10.2014).

\section{Re: Jakten på det utenomjordiske}

Ved å hevde at «den tidlige, danske beslutningen fikk flere uheldige konsekvenser», søker Aavitsland å tilbakevise min påstand om at danske myndigheter gjorde velbegrunnede vaksinasjonsbeslutninger under pandemien. Til støtte for sitt syn viser han til heftige danske vaksinasjonsdebatter, og dessuten til at danske helsemyndigheter måtte leve med usikkerheten om at epidemien kunne bli verre. Jeg finner det vanskelig å forstå at dette kan karakteriseres som uheldige konsekvenser av danskenes beslutning, for tilsvarende debatt og usikkerhet opplevde vi også i Norge. I tillegg finner jeg det bemerkelsesverdig at Aavitsland legger så stor vekt på å framheve «uheldige konsekvenser» som har lite eller ingenting med sykeligheten i befolkningen eller med vaksinens effekter å gjøre.

Relevante fakta i så måte er at Danmark hadde tilnærmet likt antall pandemidødsfall som Norge. I Danmark, hvor $6 \%$ av befolkningen ble vaksinert, døde 33 mennesker av svineinfluensa. I Norge, hvor $45 \%$ ble vaksinert, døde 32. Sammenholder vi disse tallene med at Danmark i 2009 hadde rundt 700000 flere innbyggere enn Norge, burde det bli tydelig at massevaksinasjonen gjorde lite til eller fra med hensyn til beskyttelse mot alvorlig sykdom. Når vi i tillegg tar med at danskene unngikk vaksinasjonsbivirkninger, blant annet i form av narkolepsi, kommer utsagnet om at den «danske beslutningen fikk flere uheldige konsekvenser» $\mathrm{i}$ et svært underlig lys. Og likeså gjør det tendensiøse utsagnet om at «Norske helsemyndigheter vektet nok farene for alvorlig sykdom og død mer enn de danske».

Aavitsland søker også å rettferdiggjøre den norske beslutningen ved å vise til hendelser som inntrådte året etter, i sesongen 2010-2011. Meg bekjent finnes ingen vitenskapelige undersøkelser som bygger opp under Aavitslands påstand om at vaksinasjonsulikheter i 2009 førte til ulike forløp i Norge og Danmark i 2010-2011. Men om de 